\title{
CONSTITUTION OF THE AMERICAN SECTION OF THE INTERNATIONAL ASTRONOMICAL UNION
}

(Adopted December 30, I93I; amended December 29, I940, June 29, I944, June 30, I948)

I. The Executive Committee of the U. S. A. Section shall consist of the two representatives of the American Astronomical Society on the Division of Physical and Mathematical Sciences of the National Research Council; of the President and Secretary of the American Astronomical Society; and of the American President or Vice-president (if there be one) of the International Astronomical Union. If there is no American President or Vice-president or if the President or Secretary of the Society is a member of the Division of Physical and Mathematical Sciences, or if a member die or resign before the expiration of his term, the Council of the Society shall appoint a member of the Executive Committee in replacement, so that the Committee shall always consist of at least five members. The Council may also appoint one additional member if deemed advisable. The Council of the Society shall designate one of the above members (who shall be a citizen of the United States) to serve as Chairman of the Executive Committee. The Executive Committee shall be the U. S. A. National Committee of the Union. The appointment of the chairman and the elected member of the Executive Committee shall take place at a meeting of the Council following each General Assembly of the Union and also following the election of a new president of the Society.

2. The duties of the Executive Committee shall be: to act as the representatives of the United States of America in the International Astronomical Union in the interim between meetings of the Union; to organize the U.S. A. Section and to arrange for a meeting of the Section shortly preceding each meeting of the Union; to select class (b) members of the Union (see I. A. U. By-laws I, I); and in general to deal with all questions involving the participation of the United States of America. The Chairman of the Executive Committee shall be (ex officio) a member of the Division of Foreign Relations of the National Research Council.

3. Between twelve months and six months before a meeting of the Union, the Executive Committee shall convene a meeting of the U. S. A. Section to consider matters to be recommended to the Union.

4. The U.S. A. Section shall consist of all U.S. A. members of the Union.

5. The U. S. A. Section, excepting its Executive Committee, shall automatically go out of existence at the close of each meeting of the Union.

6. The U.S. A. Section and its Executive Committee shall function under the National Research Council.

7. Amendments to the Constitution of the U.S. A. Section of the I. A. U. shall be adopted by majority vote of the American Astronomical Society at a regular meeting on submission by the Council. 
